turystyki w Łodzi, a t. 9, z. 2 (1999) poświęcono programowi studiów z geografii turyzmu i hotelarstwa w Uniwersytecie Lódzkim. Lącznie w 20 zeszytach Turyzmu, które ukazały się w latach 1991-2000, opublikowano 82 artykuły, 32 notatki naukowe, 49 sprawozdań, 39 recenzji, 14 głosów dyskusji i 15 innych prac. Autorami, obok Polaków, byli badacze z Francji, Słowacji, Białorusi, Bułgarii i Gruzji. Zawartość zeszytów Turyzmu za ten okres opublikowała E. Paradowska w t. 10, z. 2 (2000), s. 99-114.

Poczawszy od 2001 r. czasopismo zmienilo format (na A4), nieco wygląd okladki, a przede wszystkim stało się czasopismem dwujęzycznym (polskoangielskim) i od t. 17, z. 1-2 poszerzono jego Radę Redakcyjną o profesorów z uczelni zagranicznych (Michael Bonneau - Francja, Stanisław Erdavltov Kazachstan, Derek Hall - Wielka Brytania i Myriam Jansen-Verbeke - Belgia). Wśród wydanych do roku 200812 zeszytów (w ramach siedmiu tomów) znalazły się trzy dedykowane profesorom: Bernardowi Barbier (12/2, 2002), Antoniemu Jackowskiemu (15/ 1-2, 2005), Marinowi Bachvarovowi (17/ 1-2, 2007). Opublikowano również jeden zeszyt monotematyczny, poświecony regionowi turystycznemu (13/1, 2003) i jeden z okazji odbywającej się w Łodzi konferencji ATLAS, prezentujący dorobek badawczy łódzkiego ośrodka geografii turyzmu $(16 / 2,2006)$.

Turyzm ukazuje się w nakładzie 200-250 egzemplarzy (wyjątkowo 300) i jest kolportowany przez Wydawnictwo Uniwersytetu Łódzkiego zarówno w kraju, jak i za granicę (są to głównie biblioteki). W rankingu Ministerstwa Nauki i Szkolnictwa Wyższego należy do najlepiej punktowanych (4 punkty) czasopism polskich wśród wydawnictw humanistycznych. Szczegółowe informacje nt. Turyzmu można znaleźć na stronie internetowej www.turyzm.pl.

Stanisław Liszewski

\section{Folia Turistica}

W Polsce niewiele jest czasopism naukowych o charakterze ogólnokrajowym dających możliwości publikacji prac z zakresu turystyki. Należy do nich Folia Turistica, wydawana od roku 1990. przez Akademię Wychowania Fizycznego w Krakowie. W latach 1995-2006 redaktorem naczelnym była Anna Nowakowska, a jej zastępcą Zygmunt Kruczek.

Do 2007 r. wydano 17 tomów tego periodyku, czyli ukazuje się on z częstotliwością średnio jeden issues of Turyzm that appeared in 19912000 presented 82 articles, 32 academic notes, 49 reports, 39 reviews, 14 discussions and 15 other items. In addition to the Polish authors, others came from France, Slovakia, Belarus, Bulgaria and Georgia. The list of contents was compiled by Elżbieta Paradowska and published in vol. 10, issue 2 (2000), pp. 99-114.

In 2001 Turyzm changed its cover, its format to A4, and it became bilingual (Polish and English). From vol. 17, the editorial board was joined by other professors from foreign universities (Michael Bonneau France, Stanislav Erdavletov - Kazakhstan, Derek Hall - Great Britain and Myriam Jansen-Verbeke - Belgium). Among the 12 issues published before 2008 (seven volumes), three were dedicated to individuals, Profs Bernard Barbier (vol. 12, issue 2-2002), Antoni Jackowski (vol. 15, issue 1-2 - 2005) and Marin Bachvarov (vol. 17, issues 1-2 2007). The series also included one thematic issue devoted to the tourism region (vol. 13, issue 1 - 2003), and one published for the ATLAS Conference, held in Łódź, presenting the research work of the Loddz tourism geography centre (vol. 16, issue $2-2006$ ).

Turyzm has a print run of 200-250 copies (occasionally 300 ) and is distributed by its publishers, the University of Łódź, in Poland and abroad (mainly among libraries). It has received the highest rating level (four 'points') from the Ministry of Science and Higher Education making it one of the best Polish journals in the humanities.

Stanisław Liszewski

\section{Folia Turistica}

There are not many academic journals in Poland offering an opportunity to publish articles related to tourism studies that possess a nationwide character. Among the few such journals is Folia Turistica which has been published since 1990 by the Academy of Physical Education (Akademia Wychowania Fizycznego - AWF) in Kraków. By 200717 volumes, one per year, had been issued. The first two were issued by Polskie Wydawnictwa Naukowe, while subsequent volumes have 
tom w roku. Pierwsze dwa numery czasopisma firmowane były przez Polskie Wydawnictwa Naukowe, następne przez AWF w Krakowie - uczelnię o ponad 30-letnich tradycjach kształcenia kadr dla turystyki i znaczącym dorobku naukowym w zakresie nauk o turystyce (R. Winiarski, „Dorobek naukowy i edukacyjny w dziedzinie turystyki krakowskiej Akademii Wychowania Fizycznego", [w:] Turystyka $w$ badaniach naukowych $w$ Polsce $i$ na świecie, 15-17 września 2005 r. międzynarodowa konferencja naukowa $\mathrm{z}$ okazji jubileuszu 30-lecia kształcenia na kierunku turystyka i rekreacja w Akademii Wychowania Fizycznego w Krakowie, AWF Kraków - WSIiZ Rzeszów).

Koncepcja programowa Folia Turistica nawiązuje do wieloaspektowości zjawiska turystyki, dlatego zawiera ona artykuły $\mathrm{z}$ różnych dyscyplin naukowych, a zwłaszcza z zakresu geografii, socjologii, psychologii, ekonomii, ekologii i ochrony środowiska oraz rekreacji. Czasopismo stanowi również forum dyskusyjne dla problemów dydaktyki w zakresie kształcenia na kierunku turystyka i rekreacja. Jako przykład różnorodności zakresów tematycznych wymienić można takie artykuły, jak: „Ocena dostępności walorów krajoznawczych i bazy hotelowej Krakowa dla turystów niepelnosprawnych" (Z. Kruczek, K. Stanisławczyk; Folia Turistica, nr 5), „Geneza i rozwój teorii turystyki” (W. Alejziak; nr 8), „Determinanty rozwoju turystyki międzynarodowej” (R. Seweryn; nr 9), „Prawne aspekty uprawiania turystyki na obszarach chronionych” (J. Sondel; nr 17) czy „Turystyka kulturowa, krajobraz kulturowy, kultura międzyludzka" (W. Kosiński; nr 15).

Formuła czasopisma jest otwarta na różne środowiska naukowe $\mathrm{z}$ całej Polski, stwarzając szansę prezentacji dorobku naukowego zarówno znanych autorytetów $\mathrm{z}$ tej dziedziny, jak i młodych pracowników naukowych. W piśmie publikują również autorzy zagraniczni, co umożliwia umiędzynarodowienie obiegu informacji (M. Havrlant - „Ostrawska aglomeracja przemysłowa i jej wpływ na zdrowie człowieka oraz na funkcję regeneracyjną krajobrazu”; nr 7; M. Bachvarov - „Społeczno-ekonomiczne i geopolityczne zmiany na świecie i ich konsekwencje"; nr 16).

Redakcja czasopisma podjęła próbę tworzenia tomów o jednorodnej tematyce, związanej $\mathrm{z}$ istotnym działem wiedzy o turystyce lub wyselekcjonowanym zbiorem artykułów pod kątem wybranego tematu. Tom 4 z 1995 r. zatytulowano Turystyka $w$ Krakowie. Tematyka regionalna często reprezentowana jest w czasopiśmie redagowanym przez geo- been funded through the Academy of Physical Education. This research centre boasts three decades of tourism teaching and possesses outstanding academic achievements in tourism studies (R. Winiarski, Scientific and educational achievements in tourism studies at Academy of Physical Education in Krakow, [in:] Turystyka $w$ badaniach naukowych $w$ Polsce $i$ na świecie, 15-17 września $2005 \mathrm{r}$. International Academic Conference celebrating the $30^{\text {th }}$ anniversary of teaching tourism and recreation at the Academy of Physical Education in Kraków AWF, Kraków WSIiZ, Rzeszów).

The concept of Folia Turistica refers to the multifaceted character of tourism. Hence it includes articles from various disciplines, in particular geography, sociology, psychology, economics, ecology and environmental protection as well as recreation. Folia Turistica also provides a specific discussion forum where academics are able to exchange ideas on the issues encountered in lecturing in tourism and recreation.

The diversity of topics presented by Folia Turistica is extensive. Below are some examples of articles that have appeared in this journal: Assessment of the Accessibility of Kraków Sights and Hotels for Disabled Tourists (Kruczek \& Stanisławczyk, vol. 5); Theory of Tourism - History and Development: a reflection on 'Turisam ususret buducnosti' by $\mathrm{B}$. Vukonić (Alejziak, vol. 8), International Tourism Development Determinants, (Seweryn, vol. 9), Cultural tourism, cultural landscape, social culture (Kosiński, vol. 15).

As can be seen from these examples, Folia Turistica is open to different research centres in Poland. It should be emphasized that this creates an opportunity to present academic achievements both for renowned researchers as well as for young academics. International academics also publish their works in Folia Turistica which helps to spread information about this journal. Below are two articles written by foreign academics: Ostrava Industrial Agglomeration and its Influence on Human Health and the Regenerative Function of the Landscape (Havrlant, vol. 7), Global socio-demographic and geopolitical changes and their consequences for tourism (Bachvarov, vol. 16).

The editorial staff of Folia Turistica have attempted to publish volumes on specific topics by including a significant element related to tourism studies, or by publishing specialized articles on a particular subject, for 
grafów związanych z AWF w Krakowie. Tom 15 czasopisma z 2004 r. poświęcony został w większości zjawiskom turystycznym zachodzącym w regionach, co zostało zilustrowane przykładami zarówno w skali makro (krajów i regionów administracyjnych pierwszego rzędu), jak i mikro (gminy). W numerze 13 Folia Turistica zamieszczono prace dotyczące przewodnictwa górskiego w Polsce oraz dorobek specjalnej konferencji zorganizowanej w ramach obchodów Międzynarodowego Roku Gór.

W Folia Turistica prezentowane są artykuły o zróżnicowanym charakterze. Publikowane są prace będące efektem badań empirycznych, materiały stanowiące wynik uogólnienia doświadczeń praktycznych, prace o charakterze metodologicznym, dotyczące procesów regulacji sfery zjawisk turystycznych, a zatem poświęcone problemom szeroko pojętej polityki społecznej i gospodarczej, oraz prace o charakterze teoretycznym w zakresie wcześniej wymienionych dziedzin nauki. Przykładem artykułu prezentującego oryginalne badania naukowe jest publikacja M. Nowackiego „Motywy, korzyści i zadowolenia osób zwiedzających atrakcje krajoznawcze" (Folia Turistica, nr 16), natomiast egzemplifikacją prac teoretycznych jest artykuł J. Zdebskiego i R. Winiarskiego - „Psychologia turystyki w Polsce. Stan obecny i perspektywy rozwoju" (nr 1) czy analiza pojęcia rekreacji $\mathrm{w}$ polskiej tradycji terminologicznej autorstwa D. Dudka (nr 17).

Folia Turistica od 2007 r. zostala wpisana na oficjalną listę punktowanych czasopism naukowych MNiSW na potrzeby parametrycznej oceny dzialalności naukowej (4 punkty). W tym roku zmieniono też szatę graficzną i układ czasopisma. Obecnie zasadniczą częścią czasopisma jest dział „Artykuły”, ale wyodrębniono też dział „Komunikaty” oraz „Recenzje”. Nowością jest dodany dział „Z warsztatów doktoranckich" przeznaczony dla najmłodszych pracowników nauki, zobowiązanych do publikowania swoich prac wymogami przewodu doktorskiego. Przykładem takiej publikacji jest artykuł J. Zabkowskiej-Para, „Wypoczynek a nuda, lenistwo i próżniactwo" (Folia Turistica, nr 17).

Wszystkie artykuły zamieszczone w Folia Turistica są recenzowane. W skład Rady Naukowej wchodzą: S. Bosiacki, M. Duricek, R. Gałecki, S. Liszewski, J. Zdebski, funkcję redaktora naczelnego pełni obecnie Andrzej Matuszyk, sekretarza redakcji Sabina Owsianowska, a nad profilem czasopisma i doborem recenzentów czuwa Kolegium Redakcyjne (W. Alejziak, Z. Kruczek, R. Winiarski). Wszystkie artykuły mają anglojęzyczne streszczenia. example vol. 4 published in 1995 was entitled 'Tourism in Kraków'. It should be mentioned that regional topics are often presented by geographers associated with the Academy of Physical Education in 2004, vol. 15 was dedicated primarily to tourism processes that occur in specific regions. This was illustrated by examples of macro-scale processes (national and regional) as well as micro-scale (local councils). Vol. 13 of Folia Turistica focused on the profession of a mountain guide in Poland including publications and lectures presented during a special conference organized to celebrate International Mountain Year.

Folia Turistica publishes a wide variety of articles. The works published can be grouped under the following criteria: presentations based on empirical studies, results of practical investigations, methodological articles, discussions on the processes regulating tourism phenomena (related to economic and social policy), and theoretical publications. An example which presents original research is an article written by Nowacki Motives, benefits and satisfaction of heritage attraction visitors (vol. 16). An example of a theoretical article is The psychology of Tourism in Poland: its Current State and Prospects for Growth (Zdebski \& Winiarski, vol. 1), and another The concept of recreation in the tradition of Polish terminology (Dudek, vol. 17).

In 2007 Folia Turistica was registered on the official list of academic journals issued by the Ministry of Science and Higher Education MNiSW based on a performance assessment of academic activity was evaluated at the fourth (and highest) level. In the same year, both the layout and the structure were changed and currently the principle part is a section dedicated to articles, although there are also separate communication and review sections. A new section has been added called 'Doctoral Workshop' dedicated to young researchers who are required to publish as a requirement to gain a $\mathrm{PhD}$. An example is an article by Zabkowska-Para, Boredom, laziness and leisure (vol. 17).

All articles published in Folia Turistica are reviewed. The journal has its own academic committee which includes S. Bosiacki, M. Duricek, R. Gałecki, S. Liszewski, J. Zdebski. The editor is currently Andrzej Matuszyk, while the editorial secretary is Sabina Owsianowska. The editorial board is responsible for the journal's profile and selection of referees (Alejziak, Kruczek \& Winiarski). All published articles have an English summary. 
Spis treści wszystkich numerów Folia Turistica, wraz $\mathrm{z}$ abstraktami dostępny jest na stronie internetowej AWF Kraków: http://itir.awf.krakow. $\mathrm{pl} /$ folia_t2.htm\#nr3. Adres Redakcji: Akademia Wychowania Fizycznego w Krakowie, al. Jana Pawła II 78, 31-571 Kraków, tel. +48 1268312 78; e-mail: barbara.przybylo@awf.krakow.pl.

Zygmunt Kruczek

\section{Peregrinus Cracoviensis}

Wydawcą czasopisma jest Instytut Geografii i Gospodarki Przestrzennej Uniwersytetu Jagiellońskiego (Zaklad Geografii Religii). Peregrinus Cracoviensis jest periodykiem naukowym, założonym w 1995 r. z inicjatywy Antoniego Jackowskiego. Jest jedynym w Polsce i jednym $z$ nielicznych na świecie czasopism poświęconych szeroko pojętej geografii religii, a zwłaszcza problematyce pielgrzymowania we wszystkich religiach: w skali globalnej, krajowej, regionalnej i lokalnej. Do końca 2007 r. ukazało się 18 zeszytów; część z nich ma charakter monograficzny i dotyczy wybranych ośrodków pielgrzymkowych w Polsce, a także problemów teoretycznych geografii religii. Bardzo wysoko periodyk ocenial Jan $\mathrm{Pa}$ wel II.

Przewodniczącym Komitetu Redakcyjnego jest Antoni Jackowski. W skład Komitetu wchodzą: Nadine-Josette Chaline (Francja), Ludwik Kaszowski OSPPE (Uniwersytet Jagielloński), Alicja Kostrowicka (Uniwersytet Warszawski), Stanisław Liszewski (Uniwersytet Łódzki), ks. Józef Mandziuk (Uniwersytet Kardynała Stefana Wyszyńskiego, Warszawa), René Matlovič (Słowacja), ks. Maciej Ostrowski (Papieska Akademia Teologiczna, Kraków), Eugeniusz Rydz (Pomorska Akademia Pedagogiczna, Stupsk). Sekretarzami są: Elżbieta Bilska-Wodecka i Izabela Soljan.

Od dawna naukowcy reprezentujący różne dyscypliny i placówki naukowe interesowali się problematyką szeroko pojętych pielgrzymek i ośrodków kultu religijnego. Niestety studia te były prowadzone indywidualnie przez poszczególnych badaczy, a wyniki prac były znane jedynie wąskiej grupie osób. Stąd w Instytucie Geografii i Gospodarki Przestrzennej Uniwersytetu Jagiellońskiego narodziła się inicjatywa zmierzająca do zintegrowania środowiska badawczego zaj-
The table of contents of every volume published in Folia Turistica, including abstracts, is available on the $A W F$ Kraków website: http://itir.awf.krakow.pl/folia_t2.htm\#nr3. Editing address: Akademia Wychowania Fizycznego w Krakowie, al. Jana Pawla II 78, 31-571 Kraków, tel. +48 1268312 78; e-mail: barbara.przybylo@awf.krakow.pl.

Zygmunt Kruczek

\section{Peregrinus Cracoviensis}

Peregrinus Cracoviensis is a research periodical, founded in 1995 on Prof. Antoni Jackowski's initiative and published by the Institute of Geography and Spatial Management of the Jagiellonian University (Department of Geography of Religion). It is the only one in Poland and one of the few in the world devoted to what is broadly understood as the geography of religion, and in particular the issue of pilgrimage in all religions at global, national, regional and local levels. Eighteen issues had been published by the end of 2007; some of them were of a monographic nature and concerned selected pilgrimage centres in Poland, as well as the theory of the geography of religion. The periodical was highly regarded by Pope John Paul II.

The editor is Antoni Jackowski. The members of the editorial committee are Nadine-Josette Chaline (France), Ludwik Kaszowski OSPPE (Jagiellonian University), Alicja Kostrowicka (Warsaw University), Stanisław Liszewski (University of Łódź), Rev. Józef Mandziuk (Cardinal Stefan Wyszyński University, Warsaw), René Matlovič (University of Prešov, Slovakia), Rev. Maciej Ostrowski (Papal Academy of Theology, Kraków) and Eugeniusz Rydz (Pomeranian Pedagogical University, Slupsk). Secretaries: Elżbieta BilskaWodecka and Izabela Sołjan.

For a long time researchers representing various disciplines and research institutions have shown an interest in pilgrimage, as broadly understood, and in centres of religious worship. Unfortunately these studies were run independently by individual researchers, and their output was known only to a narrow group. An initiative was therefore undertaken at the Institute of Geography and Spatial Management of the Jagiellonian University to integrate the research community dealing with this field. To this end a Pilgrimage Seminar was initiated at the Institute which operated in 1994-2001 